https://doi.org/10.18778/1898-6773.52.1-2.11

\title{
Wpływ selekcji negatywnej na średnią wysokosć ciała w populacji - ujęcie ekologiczne
}

\author{
Roman Jurynec
}

THE INFLUENCE OF NEGATIVE SELECTION ON STATURE IN POPULATION - AN ECOLOGICAL APPROACH. 'The study exploited data of 2569 conscripts born in the years 1899-1901. It was assumed that the stature in the population is influenced by two factors: the living conditions and the selective pressure. These factors were assessed on the basis of data referring to the number of family members, the number of deceised brothers and sisters of the subject and the father's profession.

We wspólczesnej antropologii spoleczne zróżnicowanie populacji pod względem średnich wysokości ciala tlumaczy się lepszymi lub gorszymi warunkami środowiskowymi, przede wszystkim wplywem żywienia, chorób, obciążeń fizycznych (np. T. BIELICKI i in. [1982]). Tym bardziej wyraźnego zróżnicowania pod względem śred. nich wysokości ciala można by spodziewać się w Polsce na początku XX w., wobec przypuszczalnie bardziej drastycznych spolecznych różnic warunków środowiskowych. Jednak w ówczesnej antropologii tlumaczono różnice te glównie czynnikami genetycznymi, a w mniejszym stopniu środowiskowymi. Jan MYDLARSKI [1933] podsumowując wyniki opracowania danych pomiarowych 1273276 poboro-

Zakład Antropologii PAN ul. Kuźnicza 35, 50-951 Wrocław wych, urodzonych w latach 1906-1909, pisal: "Terytorialne rozmieszczenie średnich arytmetycznych wzrostu ogólu poborowych wskazuje na ścisly związek ze struktura rasową". W sprawozdaniu $z$ wojskowego zdjęcia antropologicznego Polski, przeprowadzonego w latach 1921-1923. J. MYDLARSKI [1925] ocenil żolnierzy z Wielkopolski i Pomorza, jako opóźnionych w rozwoju fizycznym, mimo lepszych od reszty Polski warunków ekonomicznych w tych regionach. Mimo, że zdawano sobie sprawę $z$ wplywu środowiska na rozwój, dane antropometryczne $z$ masowych badań nie daly dostatecznych podstaw dla ocen wartościujących warunki środowiskowe.

Niniejsza praca, oparta na materiale archiwalnym, próbuje wykazać niejednoznaczność ocen wartościujących warunki środowiskowe na podstawie średnich 
wysokości ciala. Stanowi także próbę potwierdzenia hipotezy o wplywie selekcji negatywnej (zróżnicowanej umieralności) na średnią wysokość ciala w populacji.

\section{Wprowadzenie}

Średnia wysokość ciala powszechnie jest używana przez antropologów do oceny "dobroci" warunków środowiskowych. $\mathrm{O}$ ile sam fakt wplywu środowiska na wysokość ciala jest niewątpliwy, to jednoznaczne wartościowanie, w każdym przypadku, dobroci warunków na podstawie średniej wysokości ciała może budzić zastrzeżenia. Średnia wysokość ciala, jako miara jakości warunków środowiskowych, dobrze spelniać może swą rolę w spoleczeństwach "dobrobytu", do jakich należą obecnie populacje krajów europejskich. Zmiany cywilizacyjne, jakie dokonaly się $w$ tych krajach w XX w., spowodowaly znaczny przyrost średnich wysokości ciala. Z socjologicznego punktu widzenia średnia wysokość ciala stanowi doskonalą miarę uczestniczenia określonych grup spolecznych w awansie cywilizacyjnym. Nie można jednak bez obaw, jak się to czyni, przenosić tych ocen do calkiem odmiennych warunków, jakie panowaly w przeszlości. Warunki środowiskowe wplywaly nie tylko na roslość, lecz także na znaczną umieralność w populacji. Nie ma podstaw by twierdzić, że zawsze istniala zgodność tych dwóch rodzajów oddzialywań środowiska. Jeżeli środowisko może $w$ silniejszym stopniu wplywać na umieralność niż na rozwój i wzrastanie, to średnia wysokość ciala w populacji nie zawsze będzie dobrze i w pelni charakteryzować jej warunki środowiskowe. Oceniając warunki tylko na pod- stawie średniej wysokości ciala jako dobre, nie można mieć pewności czy byly one równie dobre ze względu na podstawową wartość, jaką jest życie. Można również wyrazić wątpliwość, czy średnia wysokość ciala dobrze oddaje poziom niekorzystnych dla wzrastania czynników występujących w srodowisku, które jednocześnie stwarza silne zagrożenia dla życia jednostek. Pojęcie "dobroci" warunków ma charakter względny. Zależy nie tylko od wymiernych parametrów istniejących uwarunkowań środowiskowych, ale także od predyspozycji genetycznych i stopnia dostosowania jednostek do określonego zespolu czynników środowiskowych. Selekcja negatywna, eliminując jednostki najmniej dostosowane, wplywa na wzrost dostosowania w populacji, a tym samym na względną poprawę warunków. Duża umieralność, zróżnicowana względem dostosowania jednostek $w$ populacji do danych warunków, powinna wpływać dodatnio na średnią wysokość ciala osobników osiągających dojrzalość. Nawet gdy warunki dla rozwoju i wzrastania są gorsze, środowisko może częściowo kontrolować poziom niekorzystnych efektów eliminując jednostki najslabsze.

Dla opisania wpływu warunków środowiskowych na populację konieczne jest wyróżnienie czynników niekorzystnych dla rozwoju i wzrastania oraz czynników zagrażających życiu. Rozróżnienie to będzie tylko formalne, gdyż trudno realnie oddzielić od siebie te dwa aspekty oddzialywania środowiska na populację. Nie są one jednak w pelni tożsame i mogą przejawiać się jako częściowo odrębne efekty środowiskowe. Poziom i jakość zaspokojenia podstawowych potrzeb życiowych, mogące mieć wplyw na rozwój i wzrastanie jednostek, można określić jako "warunki bytowe". Ogól zagrożeń dla życia 
jednostek wywierać będzie na populację "nacisk selekcyjny".

Wplyw środowiska na średnią wysokość ciała w populacji, przy uwzględnieniu selektywnego charakteru oddzialywań środowiskowych, można przedstawić w następujący sposób. Warunki bytowe wplywają na rozwój i wzrastanie jednostek w sposób zróżnicowany. Silniejszy wplyw wywieraja na osobniki o genetycznie uwarunkowanej mniejszej ogólnej zdrowotności i mniejszej odporności na niekorzystne oddziaływanie danych czynników bytowych, słabszy - na jednostki lepiej dostosowane, odporniejsze, zdolne do zachowania homeostatycznej stabilności swego środowiska wewnętrznego w szerokim zakresie warunków bytowych. Efekty oddzialywania warunków bytowych ograniczają szansę przeżycia gorzej dostosowanych. Nacisk selekcyjny skierowany przeciw jednostkom, które w danych warunkach bytowych szczególnie silnie odchylają się od prawidlowego toru rozwojowego, wplywa na wzrost umieralności, selektywnej ze względu na skutki oddzialywania warunków bytowych na jednostki. Między prawidlowym rozwojem i wzrastaniem jednostek w populacji a selekcją negatywną zachodzi wzajemna relacja na zasadzie sprzężenia zwrotnego ujemnego. Gorszy rozwój i niższa wysokość ciala osiągana przez jednostki w populacji jest przyczyną wzrostu zróżnicowanej umieralności. Silniejsza selekcja negatywna ogranicza liczbę jednostek niskich z powodu upośledzonego rozwoju. Opisane selektywne oddzialywanie środowiska na populację, można ująć w schematyczny model (rys. 1). Średnia wysokość ciala zależy nie tylko od warunków bytowych, ale także od sily nacisku selekcyjnego, wplywającego na wzrost zróżnicowanej względem dostosowania umieralności. Selekcja negatywna pomniejsza wplyw warunków bytowych na średnią wysokość ciala. Jeżeli w oddzialywaniu środowiska na populację czynnikiem dominującym jest selekcja negatywna, to może ona wpływać na wzrost średniej wysokości ciała.

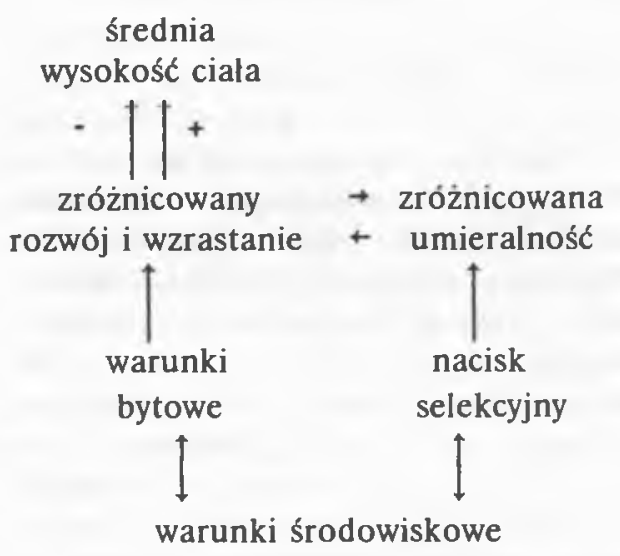

Rys. 1. Selektywny charakter oddziaływania środowiska na populację $i$ wpływ na średnią wysokość ciała.

Znaczenie nadawane pojęciu selekcji w niniejszej pracy wymaga sprecyzowania. Selekcja naturalna powodująca zmiany częstości genów w populacji nosi nazwę selekcji kierunkowej. Innym rodzajem selekcji naturalnej jest selekcja stabilizująca, przyczyniająca się do utrzymania częstości genów w populacji na stalym poziomie [BIELICKI 1969]. Selekcja stabilizująca skierowana jest przeciw zmienności rekombinacyjnej i utrzymuje populację w stanie zróżnicowania genetycznego, które stanowi podstawę plastyczności i możliwości adaptacji do zmiennych warunków środowiskowych. Zróżnicowanie genetyczne populacji umożliwia szybkie kierunkowe zmiany mikroewolucyjne poprzez selekcję kierunkową lub dryf genetyczny. Selekcja kierunkowa zachodzi w przypadku zaklócenia równowagi 
genetycznej populacji przez zmiany w środowisku lub w puli genetycznej, w wyniku mutacji i dryfu. Ze względu na dostosowanie do warunków środowiskowych osobników osiągających dojrzalość, rodzaj selekcji, kierunkowy czy stabilizacyjny, nie ma znaczenia. Dlatego przedstawiony model stanowi przede wszystkim ujęcie ekologiczne selekcji, a nie czysto ewolucyjne.

Populacje zawieraja znaczny ladunek recesywnych mutacji letalnych lub obniżających żywotność. Dobór naturalny utrzymuje staly, stosunkowo wysoki ich poziom dzięki wyższej stosowności heterozygot. Skrajne wartości, jakie przyjmują cechy poligeniczne w populacji, są na ogól mniej korzystne od wartości pośrednich i ograniczane przez dobór stabilizujący [GAJEWSKI 1977]. Można sądzić że negatywna selekcja stabilizująca, eliminując jednostki, u których ujawniają się mniej korzystne cechy genetyczne, wywiera istotny wplyw na wzrost dostosowania w populacji. Ze względu na znaczne zmiany, jakie zachodzily w środowisku czlowieka, pewną rolę mogla też odgrywać selekcja kierunkowa. Kierunkowy nacisk selekcyjny wywierać mogly zmiany w sposobie odżywiania, czy odmienne zagrożenia czynnikami chorobotwórczymi, co związane bylo z rozwojem rolnictwa, różnicami w trybie życia i większym zagęszczeniem populacji. Populacja może być $w$ dużym stopniu niejednorodna pod względem genetycznie determinowanych możliwości rozwojowych jednostek w danych warunkach bytowych. Jeżeli warunki środowiskowe nie sa dostatecznie dobre by zaspokajać wszystkie zróżnicowane wymagania jednostek, to selekcja negatywna może wywierać znaczący wplyw na średnią wysokość ciala w populacji. Na obniżanie się sredniej wysokości ciala $w$ populacji na skutek spadku śmiertelności, zwracają uwagę
Cavalli-Sforza i Ganguly [WOLAŃSKI 1976]. Selekcja negatywna nie jest jednak, na ogól, brana pod uwagę jako czynnik istotnie wplywający na średnią wysokość ciala.

\section{Material i metody}

W pracy wykorzystano część materialu wojskowego zdjęcia antropometrycznego, zebranego w okresie międzywojennym pod kierownictwem J. MYDLARSKIEGO [1925]. Analiza dotyczy żolnierzy pochodzących z regionu zachodniego Polski przedwojennej, z województwa poznańskiego i południowej części pomorskiego. Wybrano żolnierzy narodowości polskiej, urodzonych w 1899-1901 r., a badanych w latach 19211923. Liczebność materialu wynosi 2569 osób. Material ten, obok pomiarów antropometrycznych, zawiera informacje dotyczące sytuacji rodzinnej i spolecznozawodowej badanych. Pozwala to na ocenę zależności średniej wysokości ciala od zróżnicowania warunków środowiskowych. Ocena wspólzależności między warunkami środowiskowymi a średnią wysokością ciala opiera się na przyjęciu, niezależnego od wymiaru średniej, kryterium oceny "dobroci" warunków środowiskowych. Przyjętą miarą wartościowania warunków środowiskowych jest poziom zagrożeń dla życia, jakie stwarza środowisko. Jednocześnie, zgodnie z hipoteză, przyjmuje się, że średnia wysokość ciala zależy od dwóch częściowo niezależnych czynników środowiskowych "warunków bytowych" i "nacisku selekcyjnego", rozumianych w opisany poprzednio sposób. Średnie wysokości ciala oceniane sa w pracy jako sumaryczny efekt wplywu warunków bytowych i stopnia 
wyselekcjonowania badanych przez selekcję negatywną.

Dla oceny warunków środowiskowych wykorzystane zostaly dane o liczbie dzieci urodzonych oraz żywych i zmarlych w rodzinach, z których pochodzili badani. Analiza podzielona zostala na dwie części. W pierwszej, dane o rodzeństwie wykorzystane zostaly jako kryterium podzialu badanych i oceny ich warunków środowiskowych. W drugiej części badanych podzielono ze względu na zawód ojca i rangę ośrodka, w którym badany się urodzil. Jako kryterium oceny warunków środowiskowych tak wyróżnionych grup spolecznozawodowych, przyjęta zostala średnia liczba dzieci urodzonych, żywych i odsetek zmarlego rodzeństwa badanych.

Ocenę jakości warunków środowiskowych, zależnie od zastosowanych kryteriów grupowania badanych, oparto na następujących zalożeniach.

1. Duża dzietność w rodzinie, jako czynnik obciążający oraz duża umieralnośc, jako częsta konsekwencja niedostatku, świadczą o prawdopodobnie gorszych warunkach bytowych, a także środowiskowych i silniejszym nacisku selekcyjnym. Mala liczba dzieci żywych w rodzinie, jeśli nie wynika $z$ dużej umieralności wśród urodzonych, swiadczy o lepszych warunkach bytowych i środowiskowych, ale slabszej selekcji.

2. Im mniejszy odsetek zmarlych dzieci w rodzinach, $\mathrm{z}$ których pochodzili badani należący do określonej grupy spolecznozawodowej, tym lepsze warunki środowiskowe. Duża dzietność, jeśli idzie w parze z małą umieralnością, także świadczy o lepszych warunkach środowiskowych. Lepsze warunki środowiskowe mogą wynikać z korzystniejszej sytuacji bytowej lub tylko z mniejszych środowiskowych zagrożeń dla życia.

\section{Analiza wyników}

\section{Wysokość ciała a dzietność i umieralność $w$ rodzinach}

Średnia wysokość ciala dla calego materialu $(N=2569)$ wynosi $166,8 \mathrm{~cm}$. W tabeli 1 podane są wartości średnich wysokości ciala w zależności od liczby dzieci urodzonych i zmarlych w rodzinach, $z$ których pochodzili badani (różnica tych dwu liczb określa jednocześnie liczbę dzieci żywych.Zróżnicowanie średnich wysokości ciala w takim szczególowym podziale jest niewielkie i wydaje się przypadkowe. Mimo znacznych różnic w liczbie dzieci urodzonych $i$ zmarlych $w$ rodzinie, nie uwidacznia się wyraźna tendencja zmian wartości średniej. Dla oceny warunków konieczne jest uporządkowanie materiału wedlug jednego kryterium: tylko liczby dzieci urodzonych lub tylko zmarlych. Średnie wysokości ciala ze względu na liczbę dzieci urodzonych podane są w ostatniej kolumnie tabeli 1, a ze względu na liczbę zmarlego rodzeństwa - w ostatnim wierszu.

Można założyć, że im większa liczba dzieci urodzonych w rodzinie, tym większe prawdopodobieństwo gorszych warunków bytowych. Wraz ze wzrostem liczby dzieci urodzonych $w$ rodzinie systematycznie zwiększa się zarówno procent dzieci zmarlych, jak i średnia liczba dzieci żywych. Pogarszanie się warunków bytowych w miarę wzrostu liczby dzieci urodzonych nie odbija się jednak w sposób jednoznaczny na średniej wysokości ciala badanych pochodzących $z$ tych rodzin. Spadek wartości średniej wysokości ciala zaznacza się dopiero wśród badanych pochodzących $\mathrm{z}$ rodzin, w których urodzilo się ponad 11 dzieci. Przy mniejszej liczbie dzieci urodzonych brak istotnego zróżnicowania 


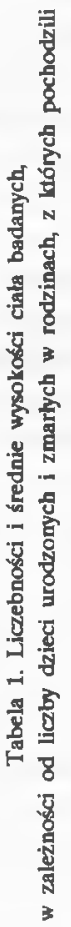

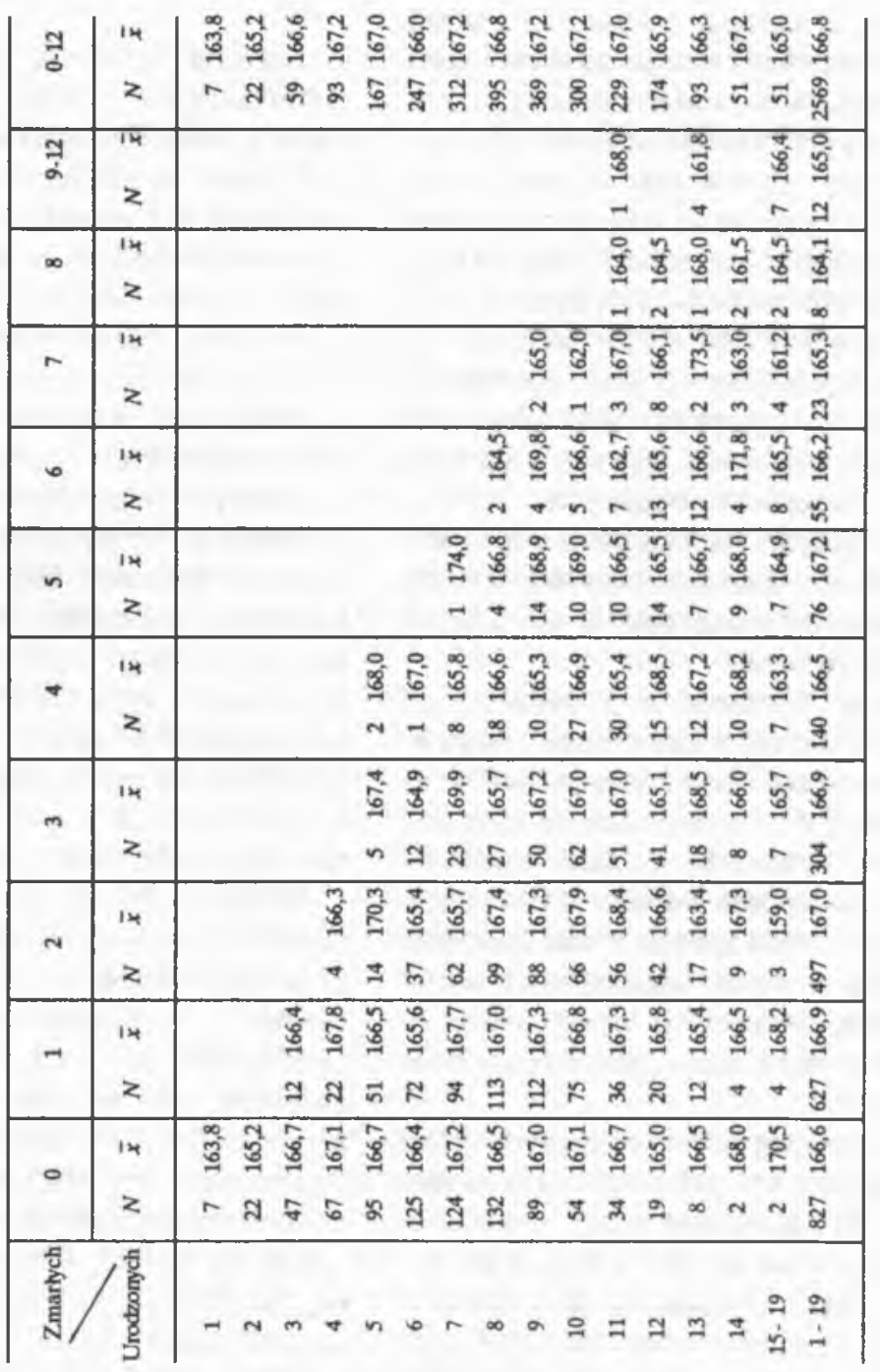


w średnich wysokości ciala. Wynik ten można, zgodnie z przyjętą hipotezą, dobrze wytlumaczyć kompensacyjnym wplywem selekcji negatywnej. Rodziny, w których rodzi się więcej dzieci stwarzają przede wszystkim gorsze warunki środowiskowe z punktu widzenia zagrożeń dla życia. Zwiększona zróżnicowana umieralność, towarzysząca przyrostowi dzietności, równoważy ujemny wpływ pogorszonych warunków bytowych, jednak $z$ wyjątkiem rodzin bardzo dużych, w których nawet silna selekcja nie jest w stanie zapobiec ujawnieniu się skutków znacznie gorszych warunków bytowych.

Jeżeli zgodzimy się z twierdzeniem, że zle warunki bytowe wplywaja niekorzystnie na przeżywanie dzieci, to możemy liczbę dzieci zmarlych w rodzinie przyjąć jako przybliżone kryterium oceny warunków bytowych. W silniejszym jednak stopniu takie kryterium różnicuje badanych pod względem warunków środowiskowych stwarzających mniejsze lub większe zagrożenia dla życia. Podane w tabeli 1 średnie wysokości ciala dla badanych o tej samej liczbie zmarlego rodzeństwa układają się podobnie jak w przypadku zależności od liczby dzieci urodzonych w rodzinie. Spadek wartości średniej zaznacza się dopiero przy 6 i większej liczbie dzieci zmarlych w rodzinie. Podobnie też można wytlumaczyć ten wynik. Badani $z$ rodzin o większej umieralności dzieci to jednostki silniej wyselekcjonowane, odporniejsze. Ogranicza to wplyw pogorszonych warunków bytowych. Badani $z$ rodzin o bardzo dużej liczbie dzieci zmarłych, chociaż przeżyły tu tylko jednostki odporniejsze, $z$ powodu szczególnie niekorzystnych warunków bytowych są średnio niżsi. Zamiast bezwzględnej liczby dzieci zmarlych w rodzinie, jako kryterium podzialu przyjąć można odsetek, jaki stanowią one spośród uro- dzonych. Silniej w tym przypadku uwypuklone zostaną rodziny mniej liczne, w których nawet niewielka liczba dzieci zmarlych stanowić może dużą część wszystkich urodzonych. Średnie wysokości ciala w zależności od procentu zmarlych dzieci w rodzinach, z których pochodzili badani, podane są w tabeli 2 .

Tabela 2. Procent dzieci zmarłych w rodzinach, z których pochodzili badani a średnia wysokośc ciala

\begin{tabular}{c|c|c}
\hline \% z marbych & $\bar{x}$ & $N$ \\
\hline 0 & 166,7 & 827 \\
do 25 & 167,0 & 1071 \\
25.50 & 166,7 & 521 \\
50 i więcej & 166,4 & 146 \\
\hline
\end{tabular}

Taki podzial w jeszcze slabszym stopniu różnicuje badanych pod względem średniej wysokości ciala. Prawdopodobnie w mniejszych rodzinach rzadziej występująskrajnie niekorzystne warunki bytowe, których wplywu nie kompensuje już silna selekcja.

Aby ocenić zależność między warunkami a wysokością ciala, można także zadać pytanie, czy osobnicy niscy częściej niż wysocy pochodzą z gorszych warunków. Gdyby warunki środowiskowe różnicowaly populację pod względem wysokości ciala, odpowiedź musialaby być twierdząca. Na to pytanie próbuje odpowiedzieć tabela 3.

Tabela 3. Procent dzieci zmarłych oraz śednia liczba dzieci (i) urodzonych i żywych w rodzinach z których pochodzili badani o określonej kategorii wysokości ciala

\begin{tabular}{l|c|c|c|c|c}
\hline Wysokościala & $\begin{array}{c}151-159 \\
N=268\end{array}$ & $\begin{array}{c}160-164 \\
N=635\end{array}$ & $\begin{array}{c}165-169 \\
N=868\end{array}$ & $\begin{array}{c}170-174 \\
N=565\end{array}$ & $\begin{array}{c}175-186 \\
N=234\end{array}$ \\
\hline \% zmartych & 19,72 & 19,35 & 18,73 & 18,63 & 18,20 \\
n urodzonych & 8,55 & 8,61 & 8,50 & 8,55 & 8,36 \\
$n$ żywych & 6,87 & 6,94 & 6,91 & 6,96 & 6,84 \\
\hline
\end{tabular}


W tabeli tej podano średnie liczby dzieci urodzonych $\mathbf{i}$ zywych oraz procent zmarłych, w zależności od kategorii wysokości ciala badanych.

We wszystkich kategoriach wysokości ciala badani pochodzą $z$ rodzin o średnio prawie takiej samej liczbie dzieci urodzonych i żywych. Zaznacza się tylko slaba tendencja, że niżsi nieco częściej pochodzą $\mathrm{z}$ rodzin o trochę większym procencie dzieci zmarlych. Można stąd wyciągnąé wniosek, że zróżnicowanie warunków środowiskowych w populacji w slabym stopniu wplywalo na wysokośc ciala badanych. Jeżeli uznać wplyw warunków środowiskowych na wysokość ciala jednostki za niewątpliwy, to bez uwzględnienia selekcji trudno ten wynik wyjaśnic. Wynik ten będzie zrozumialy jeśli przyjmiemy, że $w$ analizowanym materiale dodatni wplyw silnej selekcji negatywnej średnio byl prawie taki sam jak ujemny wplyw gorszych warunków bytowych.

Dotychczasowa analiza ujawnila wplyw na średnią wysokość ciala tylko skrajnie niekorzystnych warunków środowiskowobytowych. W lepszych warunkach bytowych, wistotny sposób na średnią wysokość ciala wplywają również czynniki środowiskowe sprzyjające silniejszej selekcji negatywnej.

Bardziej zlożona jest ocena warunków na podstawie liczby dzieci $z y-$ wych w rodzinie, będącej różnicą liczby urodzonych i zmarlych. Malodzietnośc rodziny może wynikać z niewielkiej plodności lub też z dużej umieralności wśród urodzonych dzieci. Rodziny o bardzo dużej liczbie dzieci żywych są to te nieliczne rodziny, w których przy znacznej plodności byla niewielka umieralnośc. Mimo malej umieralności nie można sądzić, by w tych rodzinach byly bardzo dobre warunki bytowe i słaby nacisk selekcyjny. Bardziej prawdopodobne jest, że urodzone w tych rodzinach dzieci cechowala większa odpornosć. W przypadku rodzin malodzietnych, niewielka umieralność świadczy o zachodzącej selekcji negatywnej, niekoniecznie jednak o silnym wyselekcjonowaniu badanych z tych rodzin, czy zdecydowanie zlych warunkach bytowych. Ujawniać się może w tych rodzinach mniejsza odpornośc dzieci na warunki. Dopiero duża umieralność przy malej liczbie dzieci żywych świadczy o zlych warunkach środowiskowych niekorzystnych dla przeżywania slabszych jednostek.

Można przyjąć, że zarówno liczba dzieci żywych jak i zmarlych, niezależnie od siebie informuje o prawdopodobnie gorszych warunkach bytowych i silniejszym nacisku selekcyjnym. Pod uwagę należy brać sumaryczna informację wynikająca $z$ obu danych. Uwzględniając powyższe przeslanki, średnie wysokości ciala obliczono dla grup badanych, pochodzących $z$ rodzin o podobnej liczbie dzieci żywych i zmarlych (tabela 4).

Wyróżniono trzy kategorie wielkości rodziny: 1-5, 6-10, 11-15 dzieci żywych, a w każdej z nich cztery kategorie ze względu na liczbę dzieci, które zmarly: 0, 1-2, 3-5, 6 i

Tabela 4. Liczba dzieci tywych i zmarlych w rodzinach, z których pochodzili badani a średnia wysokosé ciala.

\begin{tabular}{|c|c|c|c|c|c|c|c|c|}
\hline \multirow{2}{*}{$\sum_{\text {Zywych }}^{\text {Zmarhych }}$} & \multicolumn{2}{|c|}{0} & \multicolumn{2}{|c|}{$1-2$} & \multicolumn{2}{|c|}{$3-5$} & \multicolumn{2}{|c|}{6 i więcej } \\
\hline & $N$ & $\bar{x}$ & $N$ & $\bar{x}$ & $N$ & $\bar{x}$ & $N$ & $\bar{x}$ \\
\hline $1-5$ & 238 & 166,6 & 274 & 166,2 & 135 & 167,2 & 43 & 165,5 \\
\hline 6-10 & 524 & 166,8 & 781 & 167,3 & 361 & 166,8 & 53 & 165,7 \\
\hline $11-15$ & 65 & 166,3 & 69 & 165,3 & 26 & 165,2 & 0 & - \\
\hline
\end{tabular}


więcej dzieci. Srednio najniżsi są badani z kategorii skrajnych pod względem liczby dzieci żywych (11-15), oraz dzieci zmarlych (6 i więcej), a więc pochodzący $z$ warunków bytowych i srodowiskowych najmniej korzystnych. Najwyżsi są jednak badani z rodzin, które wedlug przyjętych kryteriów winny byly zapewniać średnie warunki bytowo-środowiskowe: rodzin o malej liczbie dzieci żywych (1-5) a znacznej umieralności (3-5) i $z$ rodzin o średniej dzietności (6-10), w których niewiele dzieci zmarlo (1-2). Badani $z$ rodzin o malej dzietności (1-5), w których żyly wszystkie dzieci lub zmarlo niewiele $z$ urodzonych (1-2) oraz $z$ rodzin o średniej liczbie dzieci żywych (6-10), w których żyly wszystkie urodzone, a więc $\mathrm{z}$ warunków cechujących się przede wszystkim slabszym naciskiem selekcyjnym, są nieco niżsi. Podobny uklad średnich przedstawia tabela 5, uwzględniająca mniejsze kategorie liczby dzieci żywych w rodzinie. Średnio nieco wyżsi od pozostalych są badani z rodzin średnio licznych, w których rzadko umieraly dzieci, lub $z$ rodzin

Tabela 5. Liczba dzieci ływych I zmarłych w rodzinach, z których pochodzili badani a średnia wysokosé ciaba

\begin{tabular}{r|rr|rr|rr|rr}
\hline \multirow{2}{*}{ Zmarłych } & \multicolumn{2}{|c|}{0} & \multicolumn{2}{|c|}{$1-2$} & \multicolumn{2}{|c|}{$3-5$} & 6 i więcej \\
\cline { 2 - 9 } Zywych' & $N$ & $\bar{x}$ & $N$ & $\bar{x}$ & $N$ & $\bar{x}$ & $N$ & $\bar{x}$ \\
\hline \multirow{2}{*}{$1-2$} & 29 & 164,9 & 16 & 166,4 & 9 & 168,2 & 6 & 164,7 \\
$3-4$ & 114 & 166,9 & 124 & 166,8 & 79 & 167,6 & 21 & 166,2 \\
$5-6$ & 220 & 166,6 & 372 & 166,8 & 134 & 166,8 & 34 & 165,4 \\
$7-8$ & 256 & 166,8 & 379 & 167,3 & 179 & 166,7 & 25 & 166,6 \\
$9-10$ & 143 & 167,1 & 209 & 167,1 & 95 & 166,8 & 10 & 162,8 \\
$11-12$ & 53 & 166,1 & 58 & 165,3 & 19 & 164,8 & 0 & - \\
$13-15$ & 12 & 167,4 & 11 & 165,5 & 5 & 164,2 & 0 & - \\
& & & & & & & & \\
\hline
\end{tabular}

mniejszych, w których nawet znaczna część dzieci $\mathrm{z}$ urodzonych już nie żyla, raczej więc $z$ warunków środowiskowych, które nie sprzyjały przeżywaniu jednostek slabszych, lecz pod względem bytowym nie były jeszcze drastycznie zle. Ich wyższy wzrost w porównaniu $z$ badanymi pochodzącymi z rodzin mniej licznych i o mniejszej umieralności, mimo nielepszych warunków bytowych, można uzasadnić tylko silniejszym wyselekcjonowaniem. Wplyw selekcji nie uwidacznia się już w rodzinach bardzo dużych i w takich w których zmarlo wiele $z$ urodzonych dzieci. Prawdopodobnie znajdują się tu osobnicy szczególnie odporni, którzy mimo niewyrośnięcia mają szansę przeżycia, nawet w trudnych warunkach bytowo-srodowiskowych.

Mimo dużych różnic w sytuacji rodzinnej, określonej liczbą dzieci żywych i zmarlych, otrzymane zróżnicowanie średnich wysokości ciala jest niewielkie, pozwala uchwycić jedynie pewne tendencje. Dla pelniejszej oceny istniejących różnic, dla kategorii rodzin wyróżnionych w tab. 4 obliczone zostaly rozklady procentowe w klasach wysokości o rozpiętości $3 \mathrm{~cm}$ (tab.6). Ze względu na male liczebności, badani $\mathrm{z}$ rodzin, w których zmarło $6 \mathrm{i}$ więcej dzieci lub żylo więcej niż 11, polączeni zostali w jedną kategorię. Także ze względu na liczebności, obliczono dodatkowo rozklady dla rodzin, w których żyly wszystkie urodzone dzieci - w kategoriach: 1-5, 6-8, 9-15 dzieci żywych. Rozklady te, w celu lepszego porównania zostaly przedstawione graficznie, $z$ uwzględnieniem trzech grup kategorii rodzin (rys.2): 
Tabela 6. Rozkłady procentowe wysokosci ciala badanych pochodzących $z$ rodzin o określonej liczbie dzieci żyrych (ì) i zmarłych (zm)

\begin{tabular}{l|r|r|r|r|r|r|r|r|c}
\hline $\begin{array}{r}\mathbf{z}_{2} \\
\mathrm{zm} .\end{array}$ & $\begin{array}{r}9-15 \\
0\end{array}$ & $\begin{array}{r}6-8 \\
B \cdot v\end{array}$ & $\begin{array}{r}1-5 \\
0\end{array}$ & $\begin{array}{r}1-5 \\
1-2\end{array}$ & $\begin{array}{r}1-5 \\
3-5\end{array}$ & $\begin{array}{r}6-10 \\
0\end{array}$ & $\begin{array}{r}6-10 \\
1-2\end{array}$ & $\begin{array}{r}6-10 \\
3-5\end{array}$ & $\begin{array}{c}\text { ponad 10 } \\
\text { lub ponad 6 }\end{array}$ \\
\hline 152 & 0,0 & 0,5 & 0,4 & 0,0 & 1,5 & 0,4 & 0,5 & 0,0 & 0,4 \\
155 & 1,9 & 2,4 & 4,6 & 4,7 & 3,0 & 2,3 & 1,9 & 2,8 & 3,5 \\
158 & 7,7 & 6,3 & 7,6 & 6,9 & 4,4 & 6,5 & 7,0 & 6,4 & 11,3 \\
161 & 16,8 & 15,2 & 10,1 & 17,1 & 12,6 & 15,3 & 9,6 & 12,5 & 15,6 \\
164 & 16,3 & 19,2 & 16,0 & 16,1 & 20,0 & 18,7 & 16,6 & 16,6 & 19,5 \\
167 & 18,3 & 19,9 & 21,8 & 24,4 & 18,5 & 18,9 & 23,0 & 26,0 & 19,5 \\
170 & 15,9 & 17,6 & 21,4 & 10,2 & 12,6 & 17,7 & 17,9 & 16,3 & 13,7 \\
173 & 12,5 & 10,2 & 9,2 & 10,6 & 15,6 & 11,1 & 13,6 & 11,9 & 9,0 \\
176 & 8,7 & 5,2 & 5,5 & 6,9 & 7,4 & 6,1 & 5,9 & 3,9 & 5,5 \\
179 & 1,9 & 2,4 & 3,4 & 1,8 & 4,4 & 2,3 & 2,6 & 2,8 & 0,8 \\
182 & 0,0 & 0,8 & 0,0 & 0,7 & 0,0 & 0,6 & 1,3 & 0,6 & 1,2 \\
185 & 0,0 & 0,3 & 0,0 & 0,4 & 0,0 & 0,2 & 0,0 & 0,3 & 0,0 \\
\hline$x$ & 166,8 & 166,7 & 166,6 & 166,2 & 167,2 & 166,8 & 167,3 & 166,8 & 165,7 \\
$N$ & 208 & 381 & 238 & 274 & 135 & 524 & 781 & 361 & 256 \\
\hline
\end{tabular}

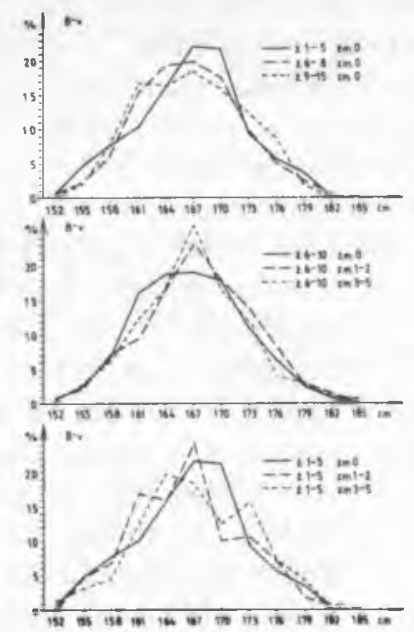

Rys. 2. Rozklady wysokosci ciała badanych pochodzących z rodzin o określonej liczbie dzieci żywych (z.) i zmarlych (zm.)

1) rodziny, w których żyly wszystkie urodzone dzieci (jak wyżej).

2) rodziny, w których żylo 6-10 dzieci, a zmarlo: 0,1-2, 3-5.

3) rodziny, w których żylo 1-5 dzieci, a zmarlo: 0, 1-2, 3-5.

W każdej grupie uwidacznia się jednolita tendencja zmian rozkladu cechy. W grupie pierwszej nie ma różnic średniej wysokości ciała, jednak im więcej dzieci w rodzinach, z których pochodzili badani, tym bardziej splaszczony jest rozklad. Wśród badanych z dużych rodzin więcej jest procentowo osobników o wzroście poniżej średniego, mniej jednak osobników skrajnie niskich. Sugeruje to malo drastyczne pogarszanie warunków bytowych i jednocześnie pewne wyselekcjonowanie badanych $z$ rodzin liczniejszych. Przy raczej nie najlepszych warunkach bytowych są to rzadziej osobnicy nieodporni, skrajnie niscy. W grupie drugiej, im większa umieralność w rodzinach, w których przeżylo 6-10 dzieci, tym rozklad bardziej wzniesiony. Najlepiej uwidacznia się tu zakladana tendencja do zmniejszania na skutek zlych warunków bytowych liczby osobników wysokich, a jednocześnie ubywanie osobników niskich, eliminowanych przez silną selekcję. W rodzinach, w których zmarlo $1-2$ dzieci, wplyw selekcji byl silniejszy i badani z tych rodzin są nieco wyżsi. W rodzinach, gdzie zmarło 3-5 dzieci, selekcja równoważyła tylko wplyw gorszych warunków bytowych $\mathrm{i}$ średnia badanych $\mathrm{z}$ tych rodzin jest identyczna jak z rodzin, w których nie zmarlo żadne dziecko. W grupie trzeciej, wraz z wzrostem liczby dzieci zmarlych w rodzinach posiadających 1-5 dzieci żyjących, zaznacza się tendencja do dwuszczytowości rozkladu. Wskazuje to na istnienie w tych rodzinach czynników sprzyjających dużej umieralności i selekcji negatywnej, 
która jednak nie zawsze rekompensuje wplyw gorszych warunków bytowych. Przyczyną może być, w przypadku rodzin o mniejszej umieralności (1-2) zbyt duża liczba osobnikow slabszych, a w przypadku większej umieralności (3-5) występowanie rodzin mających skrajnie niekorzystne warunki bytowe. Średnio najwyżsi są jednak badani $z$ rodzin, w których zmarlo 3-5 dzieci, co sugeruje, że w sumie selekcja silniej wplywa tu na wysokość ciala niż niekorzystne dla wzrastania warunki bytowe. Ksztalt rozkladów sugeruje istnienie tendencji do obniżania się $\mathrm{w}$ gorszych warunkach bytowych wysokości ciala badanych i jednocześnie do eliminacji osobników niskich pod wplywem silniejszej selekcji. Selekcja stabilizuje wartość średniej i rozklad cechy w populacji. Jej wplyw uwidacznia się tylko wśród badanych z rodzin, w których przede wszystkim istnialy warunki sprzyjające silnej selekcji, a warunki bytowe pozwalaly na w miarę prawidlowy rozwój przeżywających, odporniejszych jednostek.

Takie same wyniki w tabeli 4 otrzymano po zastąpieniu liczby dzieci zmarlych w rodzinie - procentem (tabela 7 ).

Tabela 7. Liczba dzieci żywych i procent zmarlych w rodzinach z których pochodzili badani a średnia wysokośc

\begin{tabular}{|c|c|c|c|c|c|c|c|}
\hline \multirow{2}{*}{ żywych } & 0 & \multicolumn{2}{|c|}{$0-33$} & \multicolumn{2}{|c|}{$33-50$} & \multicolumn{2}{|c|}{ ponad 50} \\
\hline & $N$ & $N$ & $\bar{x}$ & $N$ & $\bar{x}$ & $N$ & $\bar{x}$ \\
\hline $1-5$ & $238 \quad 166,6$ & 256 & 166,0 & 118 & 167,4 & 78 & 166,5 \\
\hline $6-10$ & 524166,8 & 1045 & 167,3 & 150 & 166,1 & 0 & - \\
\hline $11-15$ & 65166,3 & 95 & 165,3 & - & - & - & - \\
\hline
\end{tabular}

Można więc $w$ analizowanym materiale wyróżnić trzy grupy badanych:

1) pochodzących $z$ rodzin, w których żylo jeszcze 1-5 dzieci, a zmarło już 0 do
$33 \%$ urodzonych oraz z rodzin 6-10-dzietnych, w których wszystkie urodzone dzieci żyly (średnio najlepsze warunki bytowośrodowiskowe);

2) pochodzących $z$ rodzin, w których żylo $1-5$ dzieci, a zmarlo od $33 \%$ do $50 \%$ urodzonych oraz z rodzin, w których żylo 6-10 dzieci, a zmarlo do 33\% urodzonych (średnie warunki bytowo-środowiskowe);

3) pochodzących $z$ rodzin, w których żylo 1-5 dzieci, a zmarlo ponad $50 \%$ urodzonych, żylo 6-10 dzieci, a zmarlo ponad $33 \%$ urodzonych lub żylo 11-15 dzieci (średnio najgorsze warunki bytowośrodowiskowe).

Średnie wysokości ciala dla tak wyróżnionych grup podane są w tabeli 8. Najwyżsi są badani $z$ grupy drugiej, mimo nie najlepszych warunków bytowych. Różnica między nimi a badanymi z grupy pierwszej, oceniana testem Studenta, jest istotna na poziomie 0,01 . Wplyw gorszych warunków bytowych uwidacznia się dopiero, w niewielkim stopniu, w grupie trzeciej.

Tabela 8 . Srednia wysokośc ciała badanych pochodzących $z$ rodzin o określonej liczbie dzieci żywych i procencie zmarłych

\begin{tabular}{|c|c|c|c|c|}
\hline zywych & $\%$ zmartych & $N$ & $\bar{x}$ & $s$ \\
\hline $\begin{array}{c}1-5 \\
6-10\end{array}$ & $\begin{array}{c}\text { do } 33 \\
0\end{array}$ & 1018 & 166,6 & 5,7 \\
\hline $\begin{array}{c}1-5 \\
6-10\end{array}$ & $\begin{array}{r}33-50 \\
\text { do } 33\end{array}$ & 1163 & 167,3 & 5,6 \\
\hline $\begin{array}{c}1-5 \\
6-10 \\
11-15\end{array}$ & $\begin{array}{l}\text { ponad } 50 \\
\text { ponad } 33 \\
0 \text { i więcej }\end{array}$ & 388 & 166,0 & 5,8 \\
\hline
\end{tabular}

Największą średnią wysokość ciala w drugiej grupie badanych wytlumaczyć można tylko tym, że zastosowany podzial ujawnil tutaj rodziny, w których czynnikiem dominującym byla silna selekcja negatywna. W 
pierwszej grupie slabsze wyselekcjonowanie badanych i mniejsza ich odporność przeslaniają wplyw korzystniejszych warunków bytowych. W grupie trzeciej wplywu znacznie gorszych warunków bytowych nie kompensuje już nawet silna selekcja negatywna.

Zastosowana ocena uwzględnia przede wszystkim warunki sprzyjające silniejszej selekcji negatywnej, nie oddaje natomiast w pelni różnic warunków bytowych, a tym bardziej zamożności rodzin, z których pochodzili badani. Dlatego przy innych kryteriach oceny warunków wplyw selekcji może być trudno uchwytny fenotypowo. Dobre warunki bytowe nie wykluczają istnienia czynników środowiskowych sprzyjających silnej selekcji. Otrzymane wyniki świadczą jednak, że na średnią wysokość ciala wplywaly nie tylko czynniki bytowe, upośledzające rozwój i wzrastanie jednostek, lecz także w dużej mierze selekcja negatywna, eliminująca jednostki mniej odporne. Silniejsza selekcja negatywna, towarzysząca gorszym warunkom bytowym, ogranicza ich ujemny wplyw na wartość średniej wysokości ciala.

\section{Wysokośc ciala a pochodzenie spoleczne}

W materiale wyróżniono, ze względu na określony w karcie rodzaj pracy wykonywanej przez ojca badanego, następujące kategorie spoleczno-zawodowe: ojciec rolnik, ojciec robotnik, ojciec "fachowiec" - gdy wymienione bylo rzemioslo lub inne określone zajęcie zawodowe. Synowie robotników i "fachowców" dodatkowo podzieleni zostali na "urodzonych w mieście", gdy pochodzili z miast powiatowych i wojewódzkiego, oraz "na wsi" - w przypadku innych miejscowości. Srednie wysokości ciala, liczby dzieci urodzonych, żywych i odsetek zmarlych $w$ rodzinach dla badanych $z$ wymienionych grup spoleczno-zawodowych podane są $w$ tabeli 9.

Zgodnie $z$ przyjętymi zalożeniami, o lepszych warunkach srodowiskowych świadczy mniejsza średnia umieralność dzieci $w$ rodzinach badanych $\mathrm{z}$ danej grupy spoleczno-zawodowej. Ocena warunków na podstawie procentu zmarlych dzieci zgodna jest $z$ tą, jakiej można dokonać na podstawie dzietności. Im mniejsza umieralność dzieci, tym większa średnia liczba dzieci urodzonych i żywych. Wyjątek stanowią rodziny badanych synów "fachowców" urodzonych w mieście, charakteryzujące się trochę mniejszą dzietnością, mimo niedużej umieralności. Prawdopodobnie zaznacza się tu pewien wplyw regulacji urodzin.

Tabela 9. Zawód ojca, miejsce urodzenia a f́rednia wysokodc ciała badanych (x), oraz procent dzieci zmarłych, frednia liczba urodzonych i tywych $(\boldsymbol{n})$ w rodzinach $\mathrm{z}$ których pochodzili

\begin{tabular}{l|c|c|c|c|c}
\hline $\begin{array}{l}\text { Pochodzenie } \\
\text { spot.-zaw. }\end{array}$ & $\begin{array}{c}\text { Ojciec } \\
\text { rolnik } \\
\text { "wies" } \\
N=1066\end{array}$ & $\begin{array}{c}\text { Ojciec } \\
\text { robotnik } \\
\text { "wies" } \\
N=699\end{array}$ & $\begin{array}{c}\text { Ojciec } \\
\text { fachowiec } \\
\text { "wies" }\end{array}$ & $\begin{array}{c}\text { Ojciec } \\
\text { robotnik } \\
\text { "miasto" } \\
N=859\end{array}$ & $\begin{array}{c}\text { Ojciec } \\
\text { fachowiec } \\
\text { "miasto" } \\
N=182\end{array}$ \\
\hline $\bar{x}$ & 167,3 & 165,9 & 166,9 & 166,9 & 167,3 \\
$\%$ zmarlych & 17,4 & 20,3 & 19,8 & 22,7 & 18,9 \\
$\bar{n}$ urodzonych & 8,8 & 8,5 & 8,5 & 7,9 & 7,7 \\
$\bar{n}$ tyjacych & 7,3 & 6,8 & 6,8 & 6,1 & 6,3 \\
\hline
\end{tabular}


Wpływ selekcji negatywnej ...

Zależność między wysokością ciała a warunkami środowiskowymi, określonymi przynależnością do grupy spoleczno-zawodowej nie jest jednoznaczna. Niewątpliwie w najlepszych warunkach środowiskowych są synowie rolników, należący do najwyższych i pochodzący z rodzin o najmniejszym odsetku zmarlych dzieci. Synowie robotników i fachowców urodzeni na wsi są niżsi $i$ pochodzą $z$ rodzin o większej umieralności dzieci. Porównując miasto $\mathrm{z}$ wsią nie obserwujemy tej zgodności między średnią wysokością ciala a warunkami środowiskowymi. Badani synowie fachowców z miasta są trochę wyżsi od wiejskich i pochodzą $z$ rodzin o mniejszej umieralności dzieci, jednak mają identyczną średnią wysokosć ciala jak synowie rolników, a procent zmarlych dzieci większy. Znacznie wyraźniej rysuje się ta róźnica między synami robotników ze wsi i z miasta. Badani urodzeni w mieście są wyżsi niż na wsi, mimo że pochodzą $z$ rodzin o największym odsetku zmarlych dzieci. Miasto prawdopodobnie zapewnialo lepsze warunki bytowe rodzinom badanych, stwarzalo jednak silniejsze zagrożenia dla życia. Warunków środowiskowych w mieście nie można określić jednoznacznie jako dobre. Także podzial grupy "ojciec fachowiec" na kilka mniejszych grup zawodowych (tabela 10) nie pozwala na uchwycenie wyraźnej zależności między warunkami środowiskowymi, a średnią wysokoscią ciała. Częściej trochę wyżsi od średniej byli badani $z$ grup zawodowych cechujących się większą umieral nością dzieci w rodzinach. Można sądzić, że odgrywa tu także pewną rolę zróżnicowana umieralność.

Najniższym wzrostem wyróżniają się synowie krawców i szewców, mimo przeciętnej umieralności dzieci w rodzinach, z których pochodzili. Fakt, że krawcy i szewcy cechowali się niższym wzrostem od ogółu, znany jest w literaturze [SZCZOTKOWA 1966]. Otrzymany wynik potwierdza przypuszczenie, że spowodowane jest to kierunkowym (względem wysokości ciala doborem do zawodu. Mniejszą liczbą dzieci urodzonych w rodzinach, a jednocześnie malym procentem dzieci zmarlych, cechują się rodziny kolejarzy i urzędników. Srednio biorąc, badani $\mathrm{z}$ tych rodzin nie wyróżniają się wysokością ciala. 
W sumie, grupy spoleczno-zawodowe, które zostaly wyróżnione w materiale cechuje raczej niewielkie zróżnicowanie warunków bytowo-środowiskowych. $\mathrm{Na}$ istniejące tu niewielkie zróżnicowanie w srednich wysokości ciala wplywać mogly różnice warunków bytowych, selekcja negatywna i zależny od wzrostu dobór do zawodu. W tabeli 11 podane sa średnie wysokości ciala dla trzech podstawowych

Tabela 11. Zawód ojca a średnia wysokosć ciała badanych pochodzących $z$ rodzin o okreslonej liczbie dzieci żywych i procencie zmarbych

\begin{tabular}{|c|c|c|c|c|c|c|c|}
\hline \multirow[t]{2}{*}{ Żywych } & \multirow[t]{2}{*}{ \% zmarlych } & \multicolumn{2}{|c|}{$\begin{array}{l}\text { Ojciec } \\
\text { rolnik }\end{array}$} & \multicolumn{2}{|c|}{$\begin{array}{c}\text { Ojciec } \\
\text { robotnik }\end{array}$} & \multicolumn{2}{|c|}{$\begin{array}{c}\text { Ojciec } \\
\text { fachowiec }\end{array}$} \\
\hline & & $\boldsymbol{N}$ & $\bar{x}$ & $N$ & $\bar{x}$ & $N$ & $\bar{x}$ \\
\hline $\begin{array}{r}1-5 \\
6-10\end{array}$ & $\begin{array}{r}33 \\
0\end{array}$ & 396 & 167,1 & 305 & 165,9 & 272 & 166,7 \\
\hline $\begin{array}{r}1-5 \\
6-10\end{array}$ & $\begin{array}{l}33-50 \\
\text { do } 33\end{array}$ & 502 & 167,6 & 357 & 166,4 & 299 & 167,6 \\
\hline $\begin{array}{r}1-5 \\
6-10 \\
11-15\end{array}$ & $\begin{array}{l}\text { ponad } 50 \\
\text { ponad } 33 \\
0 \text { i wifecej }\end{array}$ & 168 & 166,6 & 125 & 164,8 & 70 & 166,5 \\
\hline
\end{tabular}

\section{Podsumowanie}

Przyjęcie w pracy biologicznych kryteriów oceny warunków środowiskowych, opartych na umieralności i dzietności dalo wyniki zgodne $z$ tezą o niejednoznacznym związku między warunkami a wysokością ciala. Wyniki potwierdzily selektywny charakter oddzialywań środowiska na populację $\mathrm{i}$ istnienie dwóch częściowo odrębnych czynników środowiskowych, "warunków bytowych" i "nacisku selekcyjnego", wplywających w sposób przeciwstawny na średnią wysokość ciala. Warunki środowiskowe sprzyjające umieralności dzieci w rodzinie mogly wplywać na wzrost średniej wysokości ciala, a umieralność prawdopodobnie byla selektywna względem dostosowania jednostek do warunków bytowych i osiąganych przez nie rozmiarów. Selekcja negatywna, poprzez zróżnicowaną umieralność eliminująca jednostki słabsze i gorzej się rozwijające,

grup zawodowych, $z$ uwzględnieniem trzech kategorii rodzin pod względem liczby dzieci żywych i odsetka zmarłych, zgodnie $\mathrm{z}$ podzialem zastosowanym $\mathrm{w}$ tabeli 8. We wszystkich trzech grupach zawodowych zaznacza się nieco wyższy wzrost badanych $z$ drugiej kategorii rodzin, a więc ze średnich warunków bytowych ale $z$ warunków środowiskowych cechujących się silnym naciskiem selekcyjnym. Potwierdza to wcześniej wyciągnięty wniosek, że selekcja negatywna może stanowić istotny czynnik wpływający na wartość średniej wysokości ciala w populacji. mogla w istotny sposób ograniczać wplyw warunków bytowych na średnią wysokość ciała w populacji.

Ograniczenie wplywu zmiennych warunków bytowych na zróżnicowanie średniej wysokości ciala można traktować jako przejaw możliwości adaptacyjnych populacji. Srednia wysokośc ciala w populacji, z powodu zróżnicowanej odporności jednostek na warunki i selekcji negatywnej, jest cechą w dużej mierze stabilną w pewnym zakresie warunków środowiskowo-bytowych. Efekt ten może być spowodowany zarówno selekcją kierunkową jak i stabilizująca. 


\section{Piśmiennictwo}

BIELICKI T., H. SZCZOTKA, J. CHARZEWSKI, S. GORNY, 1981, Rozwarstwienie spoleczne wspóteczesnej ludnosci Polski; Analiza wysokosci ciała poborowych uradzonych w 1957 r., Przegl. Antrop., 47, 237- 259.

BIELICKI T., T. DZIERŹYKRAY-ROGALSKJ, E.

PIASECKI, Z. WELON, 1969, selekeja naturalna, (w:) Mały stownik antropologiczny, 330-332, Warszawa.

GAJEWSKI W., 1972, Genetyka ogólna $i$ molekulama, Warszawa.
MYDLARSKI J., 1925, Sprawozdanie 2 wojskowego zdjęcia antropologicznego Polski, Kosmos, 50, 530-583.

MYDLARSKI J., 1933, Budowa fizyczna miadzieży męskiej roczników 1906 do 1909 w swietle materiatów komisji poborowych, Lekarz Wojskowy, 22, nr 1-4.

SZCZOTKOWA Z., 1966, Zrónicowanie morfologiczne męzczyzn pracujacych, Mat. i Prace Antr., 73, 175-258.

WOLAŃsKI N., 1976, Zmieniajqcy się czlowiek, Warszawa.

Maszynopis nadeslano w listopadzie $1985 \mathrm{r}$.

\section{S u m m a r y}

This work was based on material of military anthropological survey of Poland, which was carried out in the years 1921-1923 under the leadership of J. Mydlarski. Subject of investigation were data concerning 2569 soldiers born in the years 1899-1901 in Poznań province and the southern part of Pomeranian province. The purpose of this work was to evaluate the dependence between the environmental conditions and the mean body height in the population. The results are analysed in the light of the hypothesis about a selective character of the environmental influence on the population. In agreement with the accepted assumption, the mean body height in the population is influenced in a contrasting way by two partially different environmental factors: 'living conditions' understood as the level of satisfying the basic life needs of the individual, and 'selective pressure' being the sum of life dangers. These factors act on the individuals in a differentiated way depending on the genetic predispositions conditioning their adaptation ability, resistance and general health. The selective pressure through negative selection (differential mortality) eliminating from the population individuals who in the given living conditions develop and realize their growth potential in the poorest way limits the negative influence of living conditions on the mean body height in the population. This selection can have both a directional and stabilizing character. The mean body height of mature individuals in the population depends on the living conditions in which their development took place and on the selection degree by differential mortality.

For the evaluation of the living and environmental conditions data were utilized concerning the number of children born, living and deceased in the families from which the investigated subjects originated. On this basis the environmental conditions were evaluated both in families and in the socio-professional groups distinguished on the basis of the father's profession and the birth place ("village", "town"). In case of families, the evaluation was based on the assumption that the number of children in the family is a burdening factor, and the morality is in a great degree the effect of worse living and environmental conditions. Better environmental conditions in socio-professional groups are testified primarily by a lower percentage of deceased children in the families from which the investigated subjects belonging to the given group originate, as well as by a greater number of children. The departing point of the hypothesis accepted at the outset was the fact that in the material no definite dependence was found between the evaluated living and environmental conditions and the mean body height. The analysis of families has shown that on the average the tallest were the subjects originating from families which due to the number of living children in the family and the percentage of the deceased ones could provide the average living and environmental conditions (Tables 8 and 11). Worse environmental conditions, in case of socio-professional groups, caused by mortality and fecundity in the families from which the subjects belonging to the definite groups originated were not always connected with smaller body heights (Tables 9 and 10). 